Obaje, N. G.

Advances on the Geology and Evaluation of Potential Petroleum Systems of the Sokoto Basin in NW Nigeria.

nobaje@ibbu.edu.ng

Department of Geology, Ibrahim Badamasi Babangida University.

Nigerian National Petroleum Corporation Chair Professor in Basinal Studies.

This article is covered and protected by copyright law and all rights reserved exclusively by the

Centre for Petroleum, Pollution Control and Corrosion Studies.

(CEFPACS) Consulting Limited.

Electronic copies available to authorised users.

The link to this publication is https://ajoeer.org.ng/otn/ajoeer/qtr-2/2020/06.pdf 


\title{
ADVANCES ON THE GEOLOGY AND EVALUATION OF POTENTIAL PETROLEUM SYSTEMS OF THE SOKOTO BASIN IN NW NIGERIA
}

\author{
Obaje, N. G. ${ }^{1 / 5}$, Faruq, U. Z. ${ }^{2}$, Bomai, A. ${ }^{3}$, Moses, S. D. ${ }^{3}$, Ali, M. S. ${ }^{3}$, Adamu, S. ${ }^{3}$, Essien, \\ A. ${ }^{4}$,
}

Lamorde, U. ${ }^{4}$, Umar, U. M. ${ }^{5}$, Ozoji, T. ${ }^{5}$, Okonkwo, T. P. ${ }^{6}$, Adamu, L. ${ }^{7}$, Idris-Nda, A. ${ }^{8}$

${ }^{1}$ NNPC Chair in Basinal Studies, IBB University, Lapai, Nigeria; ${ }^{2}$ PTDF Chair, Usmanu

Danfodio University, Sokoto, Nigeria; ${ }^{3}$ Frontier Exploration Services, NNPC, Abuja, Nigeria; ${ }^{4}$ Research \& Development Division, NNPC, Portharcourt, Nigeria; ${ }^{5}$ Department of Geology, IBB University, Lapai, Nigeria; ${ }^{6}$ Department of Chemistry, IBB University, Lapai, Nigeria;

${ }^{7}$ Department of Earth Sciences, Kogi State University, Anyigba, Nigeria; ${ }^{8}$ Department of Geology, Federal University of Technology, Minna, Nigeria nobaje@ibbu.edu.ng; abdullahi.bomai@ nnpcgroup.com

IBB University = Ibrahim Badamasi Babangida University NNPC $=$ Nigerian National Petroleum Corporation

\begin{abstract}
The stratigraphy of the Sokoto Basin has the Illo/Gundumi Formation at the bottom, followed successively upward by the Taloka, Dukamaje, Wurno, Dange, Kalambaina, Gamba and Gwandu Formations. Re-mapping of the basin carried out in this study shows that the geological framework remains largely as previously outlined except that some hitherto unreported tectonically controlled structures have been documented. The basin is generally shallower at the margin and deepens towards the centre such that the areas around the border with Niger Republic are deepest and hence most prospective on the Nigerian side. Geophysical aeromagnetic interpretation has assisted to analyze the depth to basement configurations. Organic geochemical studies show that the dark shales and limestones of the Dukamaje Formation constitute the source rocks in the potential petroleum system. With averages for source rock thickness of $50 \mathrm{~m}$, area of basin of $60,000 \mathrm{~km}^{2}$, TOC of $7.5 \mathrm{wt} \%$, and HI of $212 \mathrm{mgHC} / \mathrm{gTOC}$, charge modeling indicates 808.10 million barrels of oil equivalent extractable hydrocarbons in the Sokoto Basin, at current knowledge of the geology and if the appropriate maturity has been attained at deeper sections. The sandstones of the Illo/Gundumi Formation as well as in the Taloka and Wurno Formations and carbonates of the Kalambaina Formation provide potential reservoir packages. The paper shale of the Gamba Formation and the clays of the Gwandu Formation provide regional seals. If the presently mapped tectonic structures are ubiquitous in the whole basin, structural and stratigraphic traps may upgrade the petroleum system. Other petroleum systems may exist in the basin with either or both the Illo/Gundumi and Taloka Formation(s) providing the source and reservoir rocks.
\end{abstract}

Keywords: Sokoto Basin, Dukamaje Formation, Hydrocarbons, Petroleum System, Reservoirs 


\subsection{INTRODUCTION}

The Sokoto Basin (Fig. 1) is one of Nigerian sedimentary basins that are tectonically and paleogeographically related (Fig 2-3). These basins are a part of Nigeria's inland basins that constitute another set of a series of Cretaceous and later rift basins in Central and West Africa whose origin is related to the opening of the South Atlantic (Fig. 4). Commercial hydrocarbon accumulations have been discovered in several basins within this rift structure (Fig. 4). The Sokoto Basin is predominantly a gently undulating plain with an average elevation varying from 250 to 400 metres above sea-level in north-western Nigeria. This plain is occasionally interrupted by low mesas. A low escarpment, known as the "Dange Scarp" is the most prominent feature in the basin and it is closely related to the geology. The Sokoto Basin (as so-called in Nigeria) is the south-eastern sector a larger Iullemmeden Basin. The Iullemmeden Basin itself is a broader sedimentary basin covering, apart from northwestern Nigeria, most parts of Niger, Benin, Mali, Algeria and Libya with the major depocentres situated in Niger Republic. The Sokoto sector is an out-baying marginal basin with reduced sediment thickness and stratigraphic age from the thickest and oldest in Niger Republic to the youngest towards Nigeria.

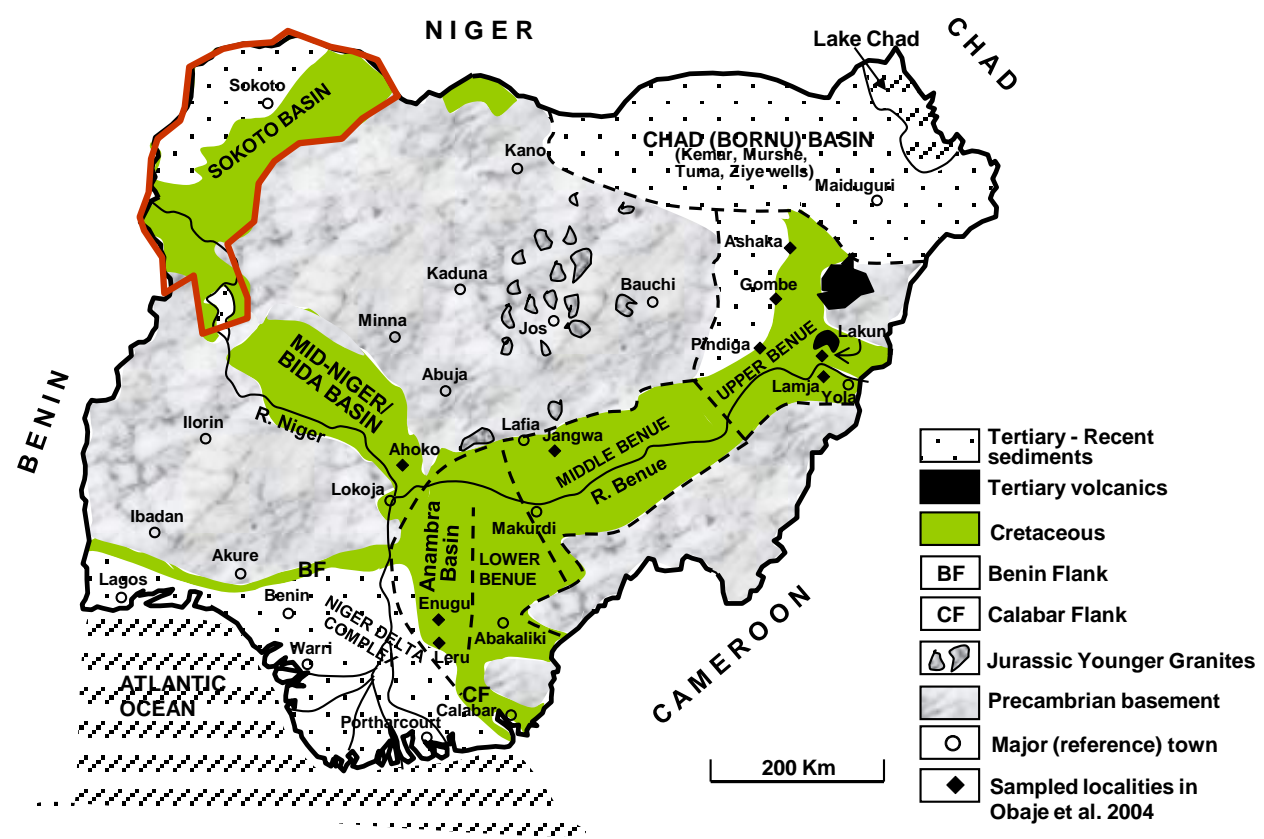

Fig. 1. Generalized geological map of Nigeria showing the location of the Sokoto Basin 

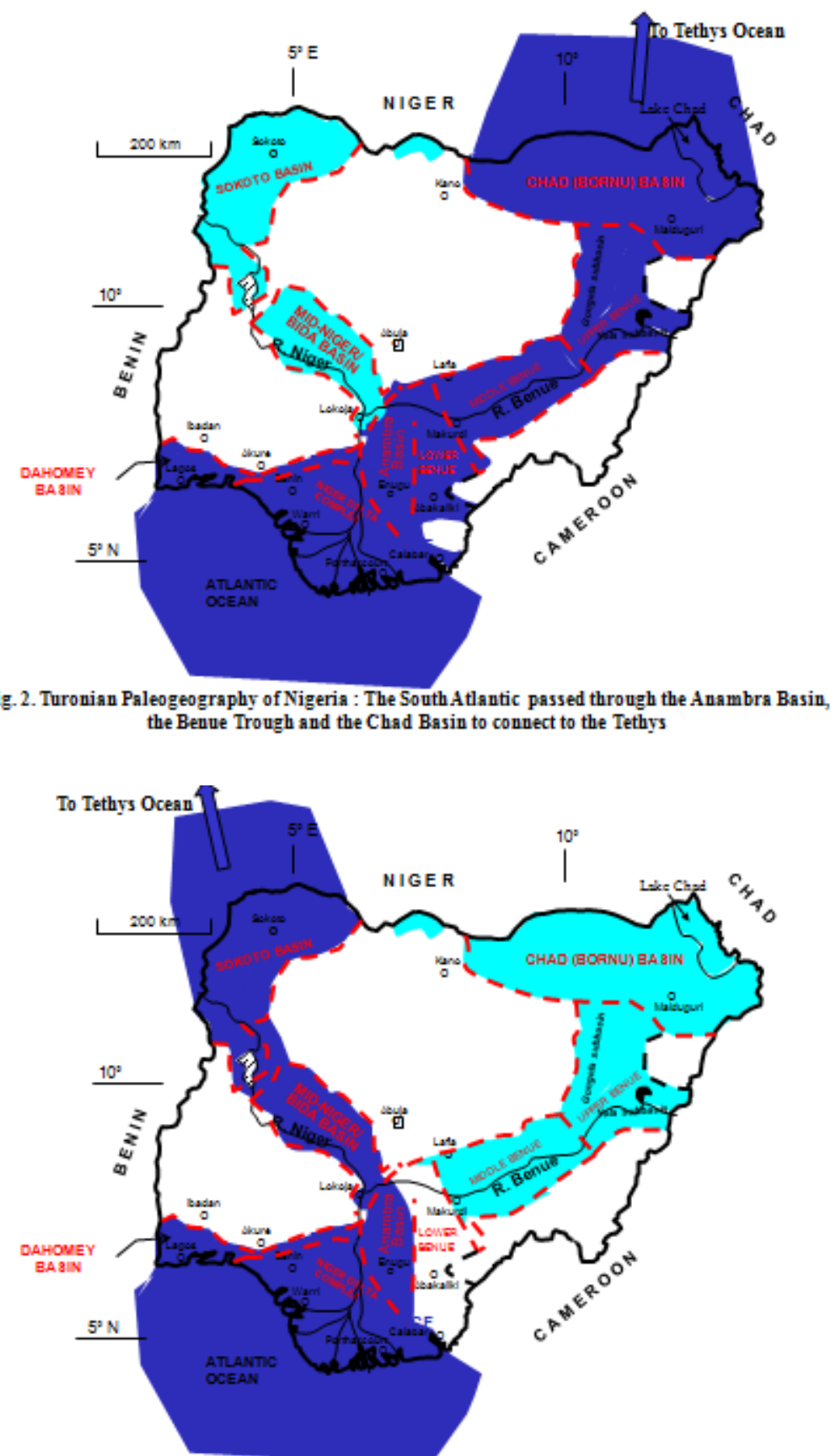

Fig. 3. Masstrichtian Paleogeography of Nigeria: The South Atlantic passed through the Anambra, Bida and Solroto Basius to connect to the Tethys 


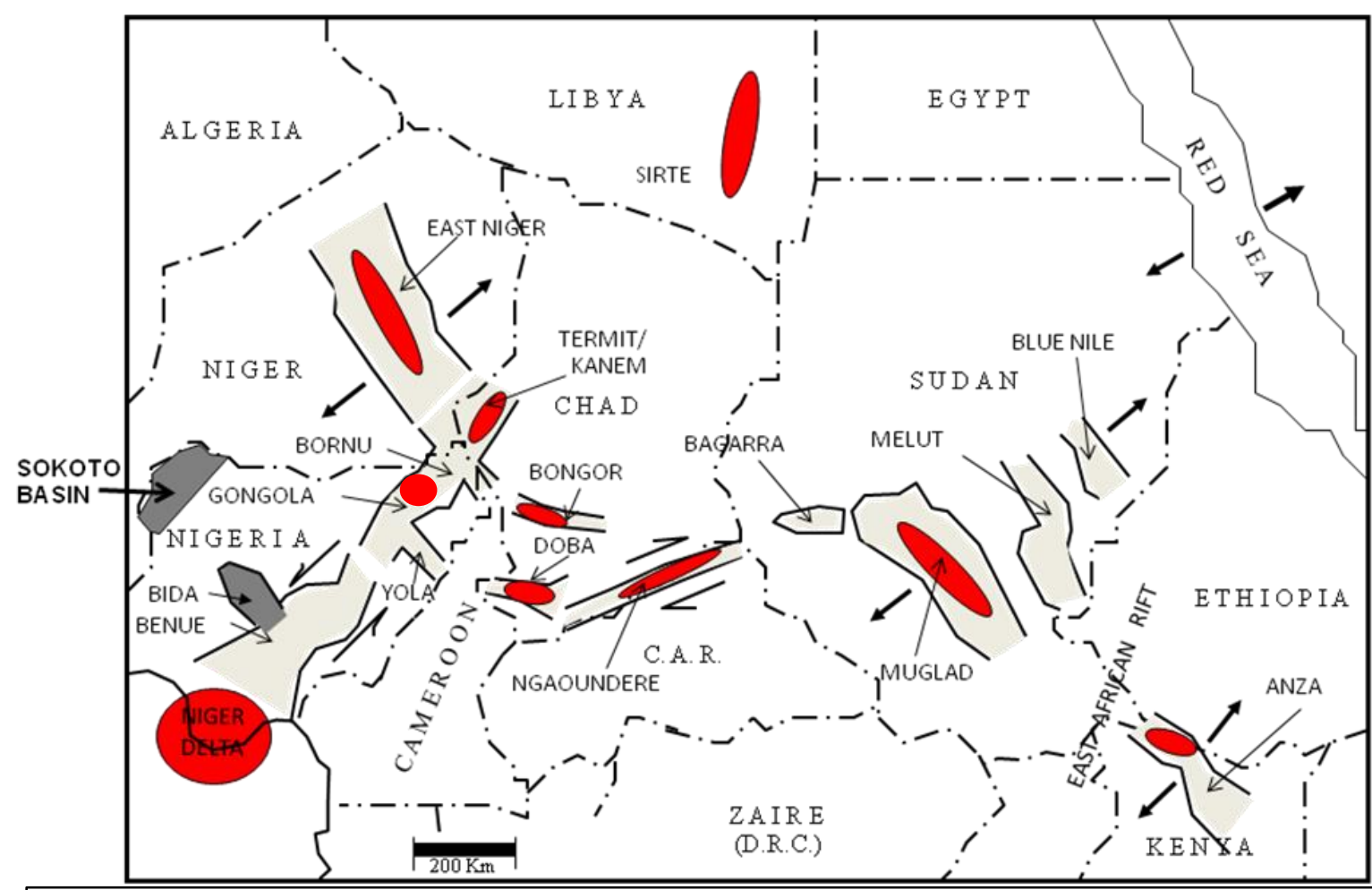

Fig. 4. The Bida and Sokoto Basins are part of the western, central and eastern

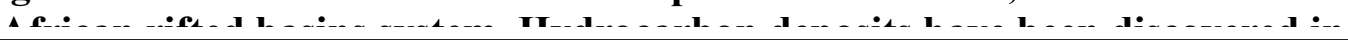

Major oil and/or gas discovery

\subsection{MATERIALS AND METHODS}

The sediments of the Iullemmeden Basin were accumulated during four main phases of deposition. Overlying the Pre-Cambrian Basement unconformably, the Illo and Gundumi Formations, made up of grits and clays, constitute the pre-Maastrichtian "Continental Intercalaire" of West Africa. They are overlain unconformably by the Maastrichtian Rima Group, consisting of mudstones and friable sandstones (Taloka and Wurno Formations), separated by the fossiliferous, calcareous and shaley Dukamaje Formation. The Dange and Gamba Formations (mainly shales) separated by the calcareous Kalambaina Formation constitute the Paleocene Sokoto Group. The overlying continental Gwandu Formation forms the Eocene Continental Terminal. These sediments dip gently and thicken gradually towards the northwest with maximum thicknesses attainable toward the border with Niger Republic. The stratigraphic succession in the Sokoto Basin is as shown in Figure 5. 


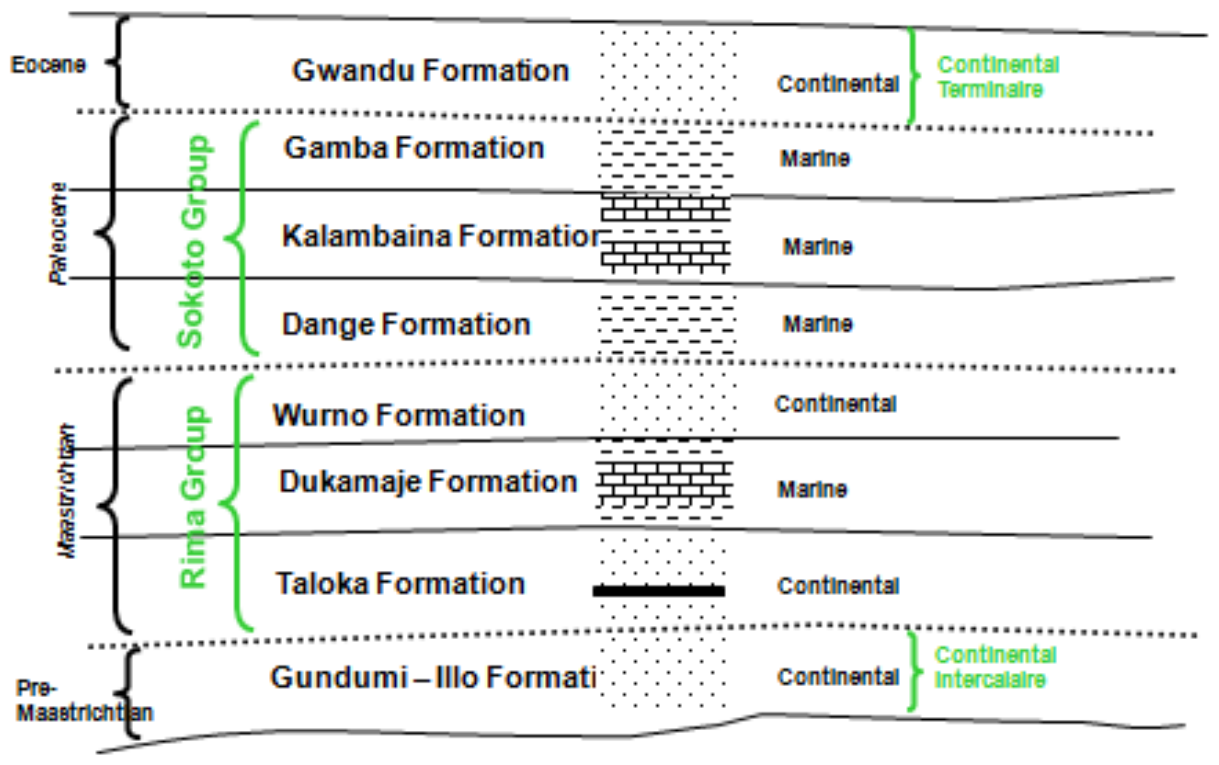

Fig. 5. Stratigraphic formations in the Sokoto Basin of North-western Nigeria (After Kogbe, 1981; Obaje et al.,2013)

The "Continental Intercalaire" is important in Africa. The Karoo Series of South Africa can be correlated with the upper beds of the lower portion of the "Continental Intercalaire" (Adeleye, 1975; Kogbe, 1981). The "Continental Intercalaire" corresponds to the upper part of the Nubian Sandstone, which, in the Arabo-Nubian shield, begins at the base of the Palaeozoic. The Iullemmeden Basin, as well as many other parts of North and South Africa experienced extensive periods of continental sedimentation with the accumulation of fluviolacustrine sediments in pre-Cenomanian times. The northern limit of the continental deposition coincides with the Algeria-Moroccan Sahara and extends eastward into Egypt and the Sudan. The southern limits extend as far as South Africa.

\subsection{RESULTS AND DISCUSSION}

Detailed geological mapping was carried by the authors as augmentation to the work of the team of geologists from the Ahmadu Bello University, Zaria under the leadership of Prof. C. A. Kogbe whose reports were published in Kogbe $(1979,1981)$. This information was complemented by the work of Petters (1982) and Obaje et al. (2013). On the basis of geological traverses taken across the basin (Fig. 6) the geological map shown in Figure 7 has been prepared. The geological mapping undertaken reveals some details of the composition and aerial extent as well as the inferred boundaries of the formations in the Sokoto Basin. The delineation of inferred boundaries between the formations in the basin is a significant 
criterion in evaluating the hydrocarbon prospectivity. Subsurface reservoir characteristics were also inferred from outcrop-stratigraphic sections encountered during the geological mapping exercise. The geological map, in a general assessment, conforms to earlier maps produced by previous workers with some minor modifications. For example, the organic matter-rich carbonaceous shales within the Taloka Formation at Goronyo are first identified in this study. Cross-sections across the basin show the Sokoto Basin deepens towards the border with Niger Republic (Fig. 8a-b).
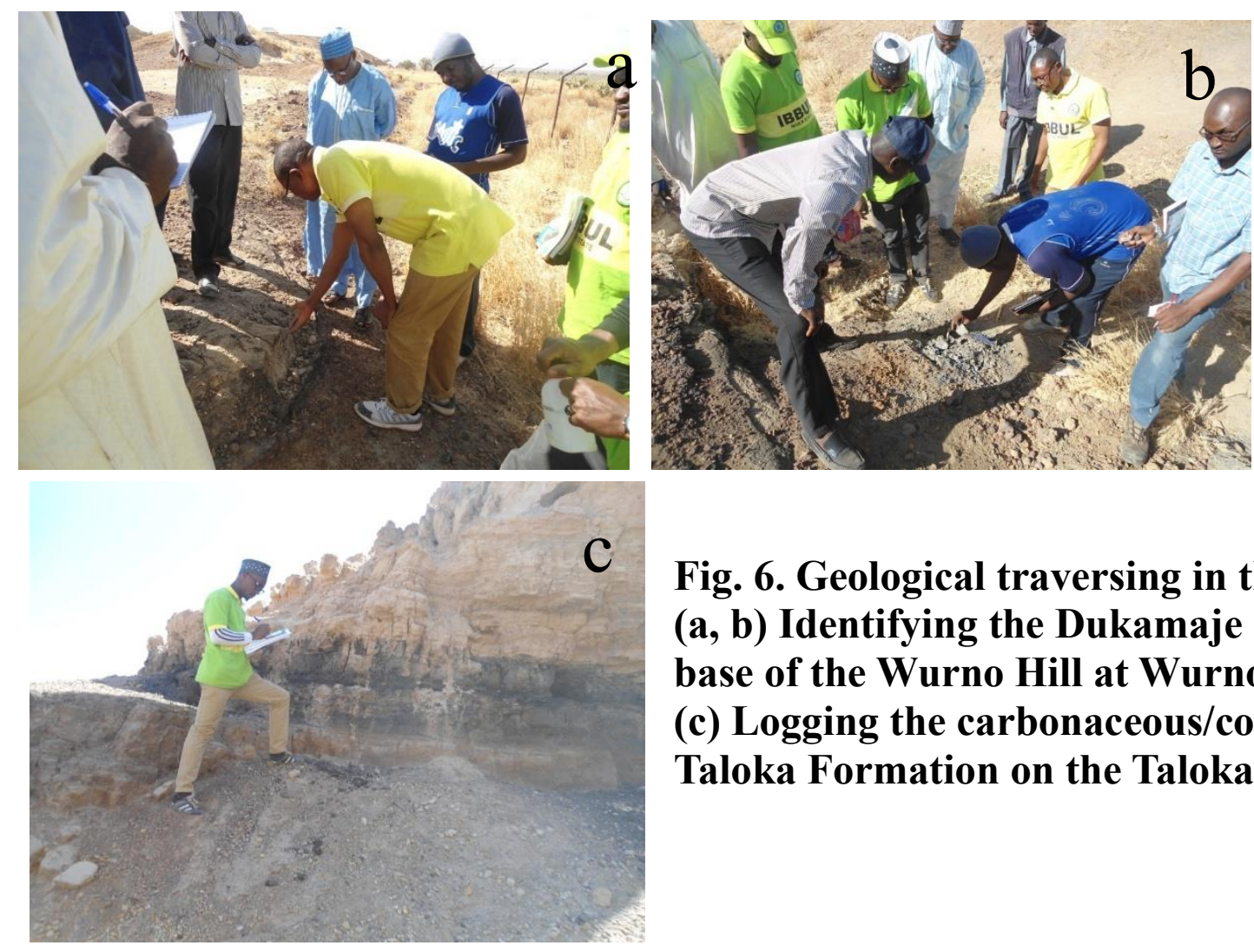

Fig. 6. Geological traversing in the Sokoto Basin (a, b) Identifying the Dukamaje Formation at the base of the Wurno Hill at Wurno village (c) Logging the carbonaceous/coaly facies of the Taloka Formation on the Taloka- Goronyo road. 


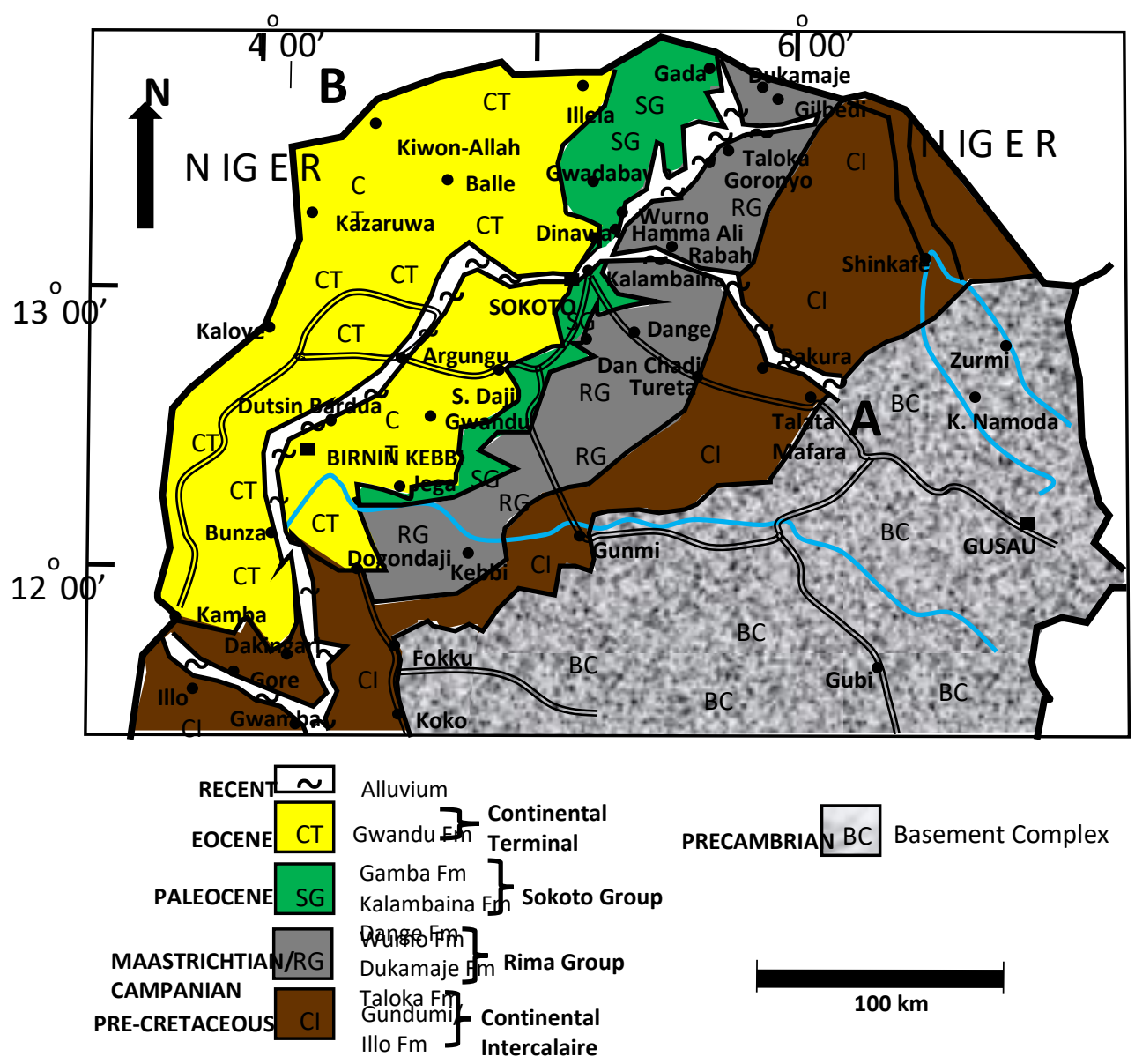

Fig. 7. Updated geological map of the Sokoto Basin (prepared in this study) 


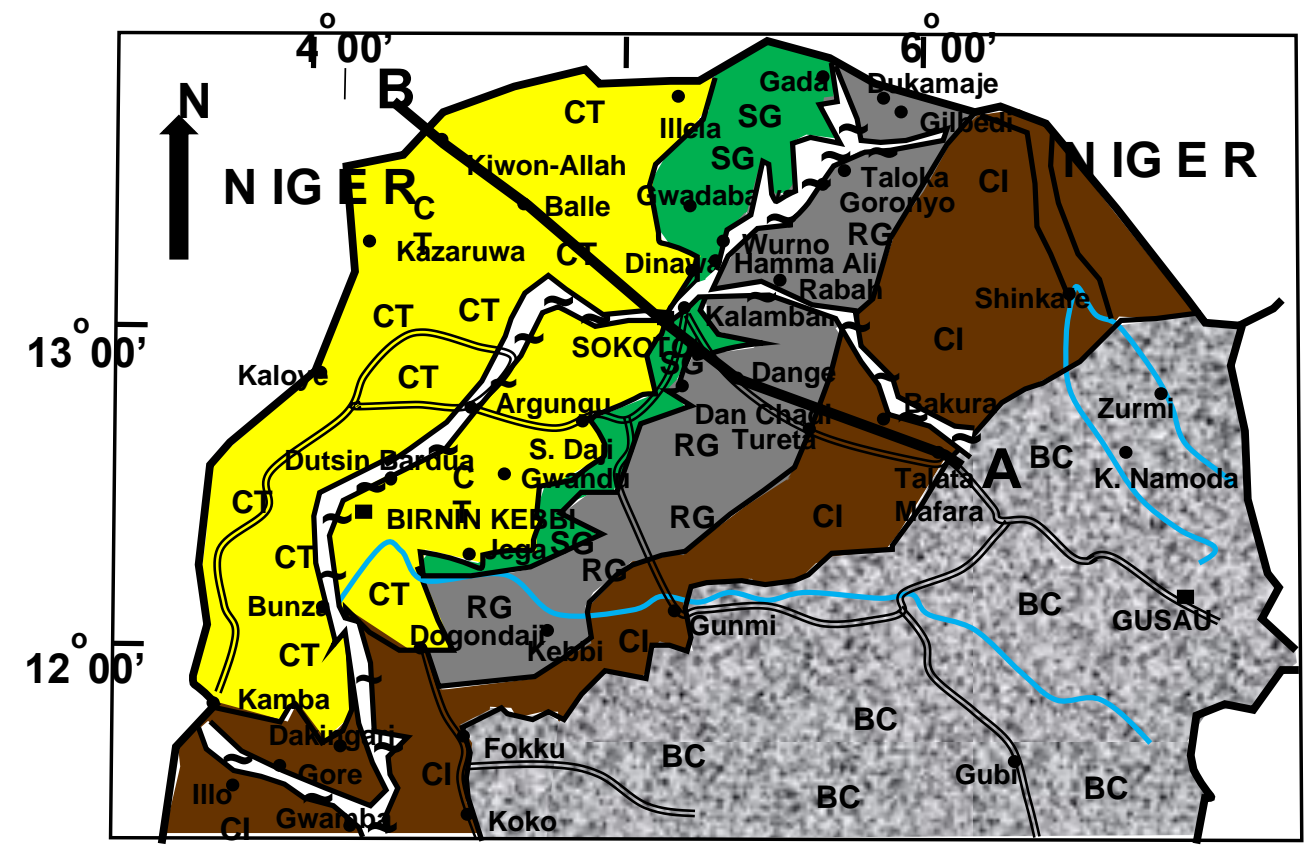

NW Increasing prospectivity

SE

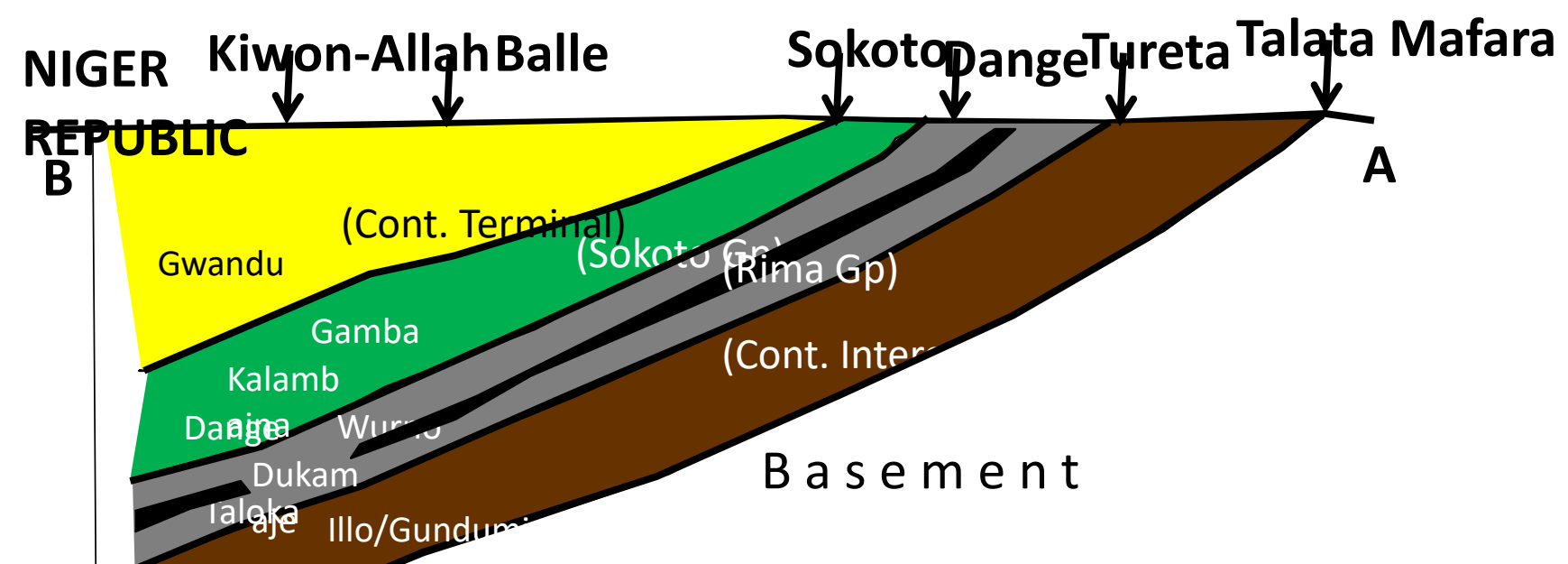

Approx. 2000tepth
Fig. 8a. Line of section A-B (Talata Mafara - Kiwon-Allah) sho that geologically most prospective areas are towards the border Niger Republic as the sediment piles get thicker. Aeromagnetic and seismic data interpretation may result in a different scenario.

(Cross-sectional scale exaggerated) 

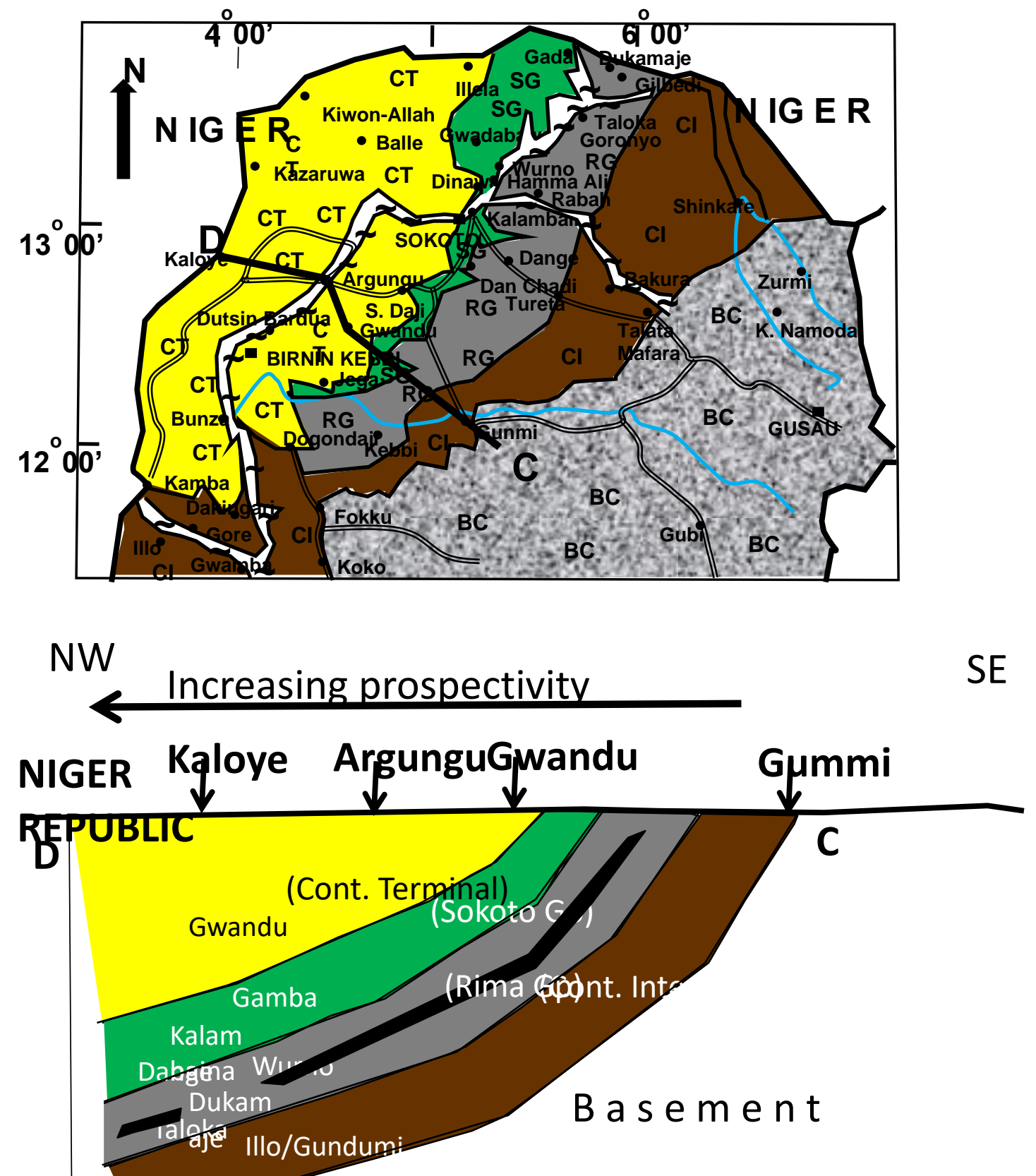

Approx. $2000 \mathrm{~m}$ depth
Fig. 8b. Line of section C-D (GummiKaloye) showing that geologically most prospective areas are towards the border with Niger Republic as the sediment piles get thicker. Aeromagnetic and seismic data interpretation may result in a different scenario.

(Cross-sectional scale exaggerated) 


\subsection{AEROMAGNETIC GEOPHYSICS}

Preliminary interpretation of the geophysical aeromagnetic data over the Sokoto Basin (Fig. 9) agrees generally with the geological mapping interpretation that shows that prospectivity increases towards the border with Niger Republic but with the addition of prospective areas in updip sections of the basin around Tureta, Bakura, SabonBirni and Isah located on the Illo/Gundumi/Taloka Formations. The interpreted aeromagnetic data map shows many troughs, trenches, ditches, sinks and holes (prospective areas) (indicated in blue). However, eight areas are discernibly highly ranked at this stage, pending future seismic investigations. These areas comprise the:

1. Yerimawa-SabonBirni-Isah trough

2. Wurno-Rabah trench

3. Sokoto-Bodinga-Tambulwa trench

4. Tureta-Bakura ditches

5. Lema-Tambo sinks

6. Koko-Giro sinks

7. Gada holes

8. Kiwon Allah-Sokwoi-Illela pits

Although the interpreted aeromagnetic data did not give exact depth to basement, it has indicated that most of the identified prospective areas have sediment thickness up to $3,000 \mathrm{~m}$ $(3 \mathrm{~km})$.

In the Sokoto Basin, the sandstones of the Illo/Gundumi Formation as well as in the Taloka and Wurno Formations and carbonates of the Kalambaina Formation provide potential reservoir packages. The paper shale of the Gamba Formation and the clays of the Gwandu Formation provide regional seals. 


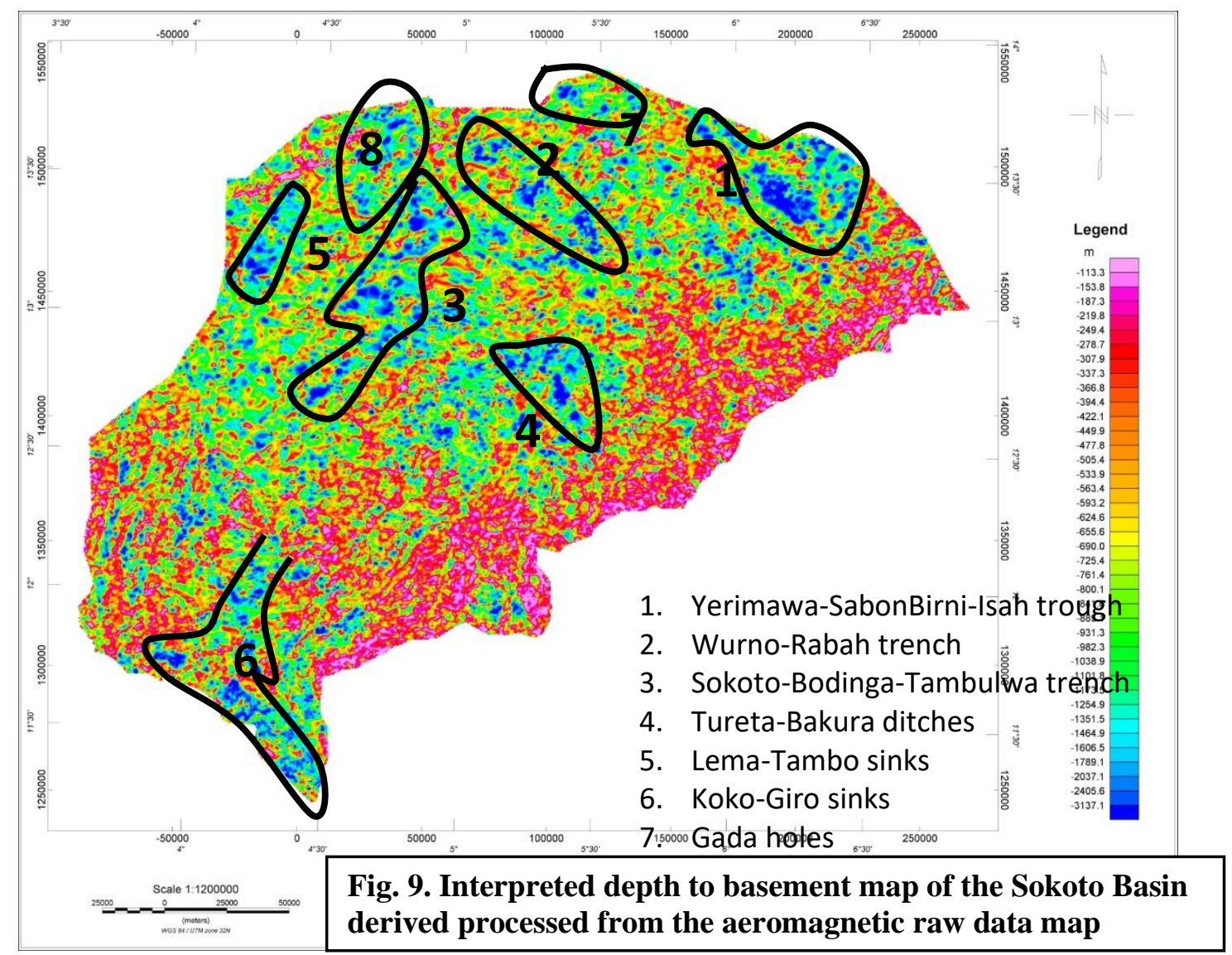

\subsection{GEOCHEMISTRY AND CHARGE MODELING}

Table 1 shows the Leco-TOC and Rock-Eval pyrolysis results of some representative samples obtained from outcrops and shallow wells drilled at Wurno, Goronyo, Gada, Illela and Sokoto township. Ninety percent of the samples examined have equal or more than the minimum limit of TOC value $(0.5 \mathrm{wt} \%)$ required to initiate hydrocarbon generation from source rocks. TOC decreases with depth in the Gada (GAD) borehole and increases with depth in the Wurno (WUR) borehole down until $27 \mathrm{~m}$.

Evaluation of maturity level by Tmax shows that the source rocks (made up of the carbonaceous shale intervals of the Taloka and Dukamaje Formations) are sub-mature (Wurno samples) through marginally mature (Gada samples) to mature within the main oil window (Goronyo and Illela samples). 
Juxtaposition of the HI against the Tmax (thermal maturity) (Fig. 10) shows that the source rocks in the Sokoto Basin are slightly below the entrant to the oil window (slightly immature to early mature) (Wurno and Gada samples) to appropriately mature within the main oil window (Goronyo and Illela samples). The interpretation, however, represents results on samples obtained at the surface to maximum $120 \mathrm{~m}$ depth. At greater depths, majority of the samples would have entered the main oil window to generate mainly gas and some oil.

With averages for source rock thickness of $50 \mathrm{~m}$, area of basin of $60,000 \mathrm{~km}^{2}$, TOC of $7.5 \mathrm{wt} \%$, and $\mathrm{HI}$ of $212 \mathrm{mgHC} / \mathrm{gTOC}$ (putting several results together), charge modeling indicates 808.10 million barrels of oil equivalent extractable hydrocarbons in the Sokoto Basin, if the appropriate maturity has been attained at deeper sections and if other petroleum system requirements are available (good quality reservoir, traps, etc).

\begin{tabular}{|c|c|c|c|c|c|}
\hline \multicolumn{2}{|c|}{ the Sakpigto Basigample Type } & \multirow{2}{*}{$\begin{array}{r}\text { TOC } \\
10.93\end{array}$} & \multirow{2}{*}{$\begin{array}{c}\text { HI } \\
307\end{array}$} & \multirow{2}{*}{$\begin{array}{l}\text { OI } \\
30\end{array}$} & \multirow{2}{*}{$\begin{array}{c}\text { Tmax } \\
429\end{array}$} \\
\hline GAD-DK-51 & Borehole & & & & \\
\hline GAD-DK-57 & Borehole & 3.91 & 218 & 36 & 432 \\
\hline GAD-DK-63 & Borehole & 3.55 & 172 & 44 & 432 \\
\hline GAD-DK-72 & Borehole & 3.59 & 111 & 42 & 433 \\
\hline GAD-DK-75 & Borehole & 3.48 & 135 & 39 & 431 \\
\hline GAD-DK-78 & Borehole & 2.86 & 110 & 69 & 434 \\
\hline GAD-DK-84 & Borehole & 2.94 & 144 & 40 & 431 \\
\hline GOR-DK-1 & Outcrop & 0.59 & 27 & 95 & 499 \\
\hline GOR-DK-2 & Outcrop & 0.50 & 44 & 131 & 445 \\
\hline GOR-DK-22 & Borehole & 1.09 & 86 & 128 & 435 \\
\hline ILE-DK-80 & Borehole & 0.23 & 130 & 485 & 546 \\
\hline ILE-DK-110 & Borehole & 0.92 & 73 & 92 & 434 \\
\hline SOK-DK-4 & Borehole & 2.01 & 149 & 46 & 433 \\
\hline WUR-DK-3 & Borehole & 0.01 & 1300 & 5800 & 467 \\
\hline WUR-DK-16 & Borehole & 2.03 & 42 & 67 & 435 \\
\hline WUR-DK-22 & Borehole & 3.18 & 117 & 44 & 426 \\
\hline WUR-DK-24 & Borehole & 7.14 & 152 & 35 & 425 \\
\hline WUR-DK-27 & Borehole & 5.53 & 112 & 43 & 423 \\
\hline WUR-DK-33 & Borehole & 2.67 & 137 & 48 & 427 \\
\hline WUR-DK-39 & Borehole & 2.30 & 139 & 52 & 429 \\
\hline
\end{tabular}




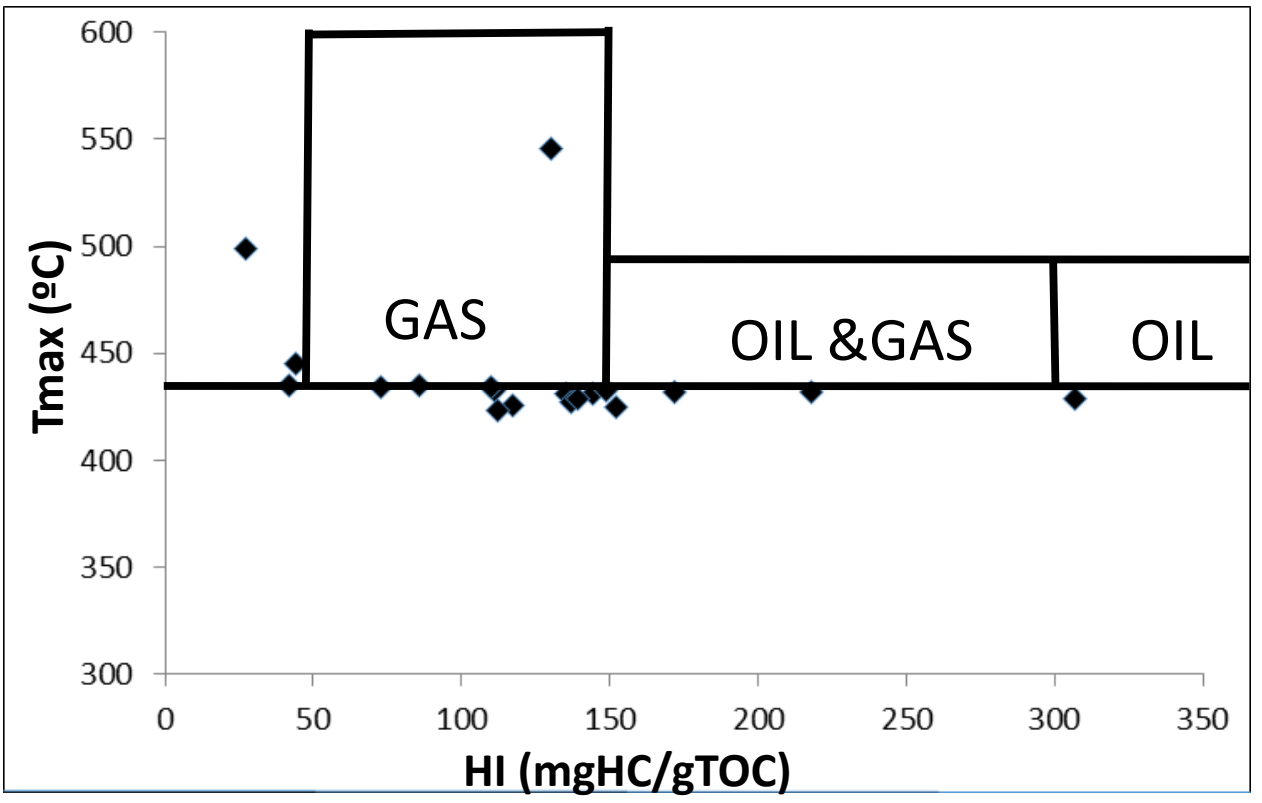

Fig. 10. Plot of HI versus Tmax values of samples from the Sokoto Basin. Majority of the samples are immature to marginally mature at the present sampling depth level. At greater depths of more than $1,000 \mathrm{~m}$, majority of the samples would have entered the oil window to generate mainly gas and some oil.

\subsection{Potential Petroleum System}

Some lacustrine carbonaceous shales within the Continental Intercalaire could constitute potential source rocks. The Dukamje Formation (Maastrichtian) is the major potential source rock in the Sokoto Basin. It correlates with the Nkporo Shale in the Anambra Basin and the Enagi/Patti Formation in the Mid-Niger (Bida) Basin. Sandstone facies in all the formations and the large carbonate deposits of the Kalambaina Formation are potential reservoir rocks. The Dange and Gamba shales as well as the thick clays within the Gwandu Formation constitute regional seals. Some folded and reversed fault structures have been mapped on outcrops and sections exposed along the Goronyo - Taloka road (Fig. 11). If these mapped tectonic structures are ubiquitous in the whole basin, structural and stratigraphic traps may upgrade the petroleum systems. 

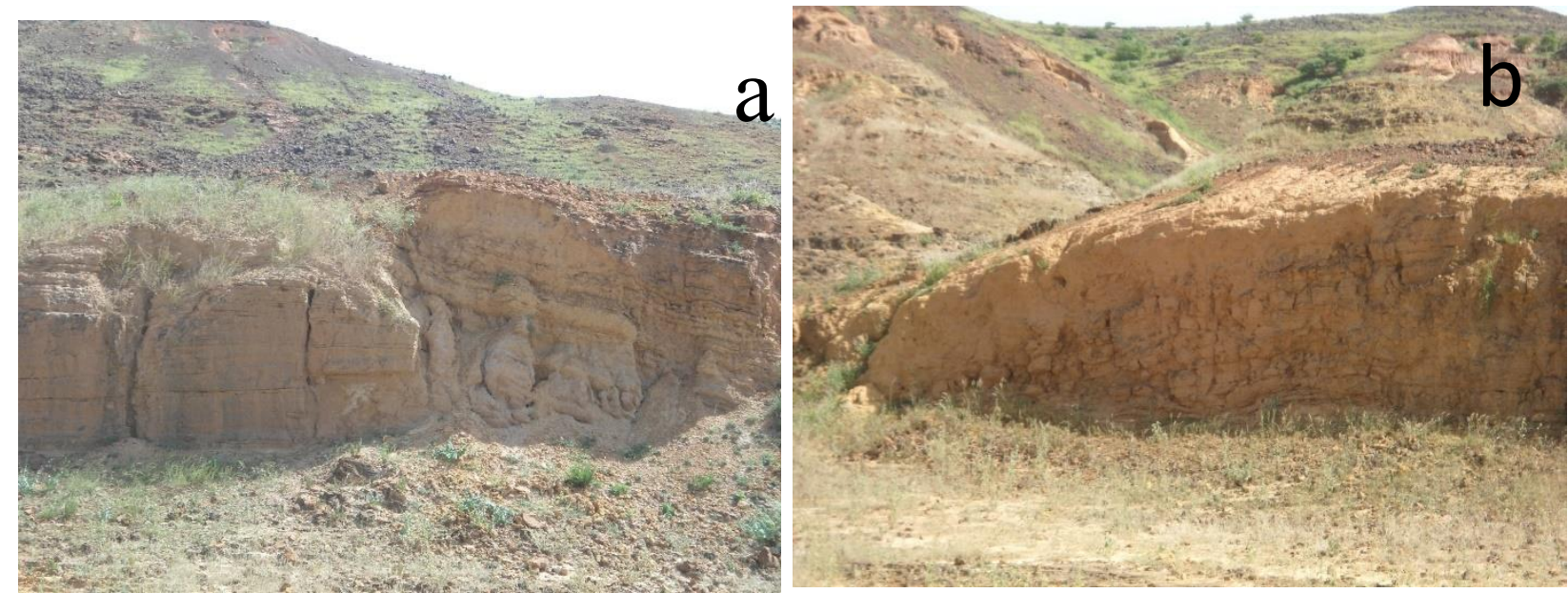

Fig. 11. Tectonic features in the Sokoto Basin within the Taloka Formation on the

\section{Taloka-Goronyo road: (a) Reverse fault? (b) rollover anticline?}

\section{0: CONCLUSION}

The Sokoto Basin is one of Nigeria's inland frontier basins. The origin of these basins is related to the opening of the South Atlantic and the accompanying rifting in many areas of Western and Central Africa. Basinal fills comprising pre-Campanian fluvio-deltaic sediments, Campanian-Maastrichtian continental and marginal marine sediments as well as marine Paleocene and continental Eocene sediments make up the sediment fills in the Sokoto Basin. Source rocks of Campanian-Maastrichtian age run in a linear belt from the Anambra Basin in the southeast through the Bida Basin in the central region into the Sokoto Basin in the northwest of Nigeria. Potential petroleum systems exist in the Sokoto Basin. Geochemical results obtained on surface and near surface samples from the basins, however, show that organic matter in the source rocks are immature to sub-mature but may have attained the appropriate maturity at deeper depths to generate mainly gas and some oil. Structures related to tectonics had not been previously documented in the Sokoto Basin. This paper has brought some new insights on the possible existence of tectonically originated structures in the Sokoto Basin. 


\section{ACKNOWLEDGEMENTS}

The Nigerian National Petroleum Corporation, the Ibrahim Badamasi Babangida University Lapai and the Sokoto State Government supported this work in different ways.

\section{REFERENCES}

Kogbe, C. A. 1979. Geology of the South-eastern (Sokoto) Sector of the lullemmeden Basin. Dept. of Geology, Ahmadu Bello. University Zaria Bulletin 32, 142pp

Kogbe, C. A. 1981. Cretaceous and Tertiary of the Iullemmeden Basin of Nigeria (West Africa). Cretaceous Research 2, 129-186.

Obaje, N. G., Wehner, H., Scheeder, G., Abubakar, M. B. and Jauro, A. 2004. Hydrocarbon prospectivity of Nigeria's inland basins: from the viewpoint of organic geochemistry and organic petrology. AAPG Bulletin 87, 325-353.

Obaje, N. G., Aduku, M., and Yusuf, I. 2013. The Sokoto Basin of Northwestern Nigeria: A preliminary assessment of the hydrocarbon prospectivity. Petroleum Technology Development Journal 3 (2), 71-86..

Petters. S. W. 1982. Central West African Cretaceous-Tertiary benthic foraminifera and stratigraphy. Palaeontographica Abt. A 179, 1-104. 